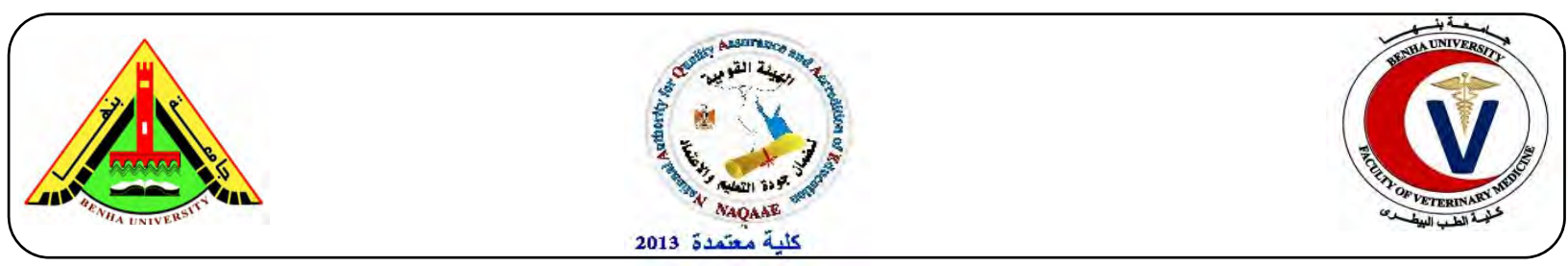

\title{
Biochemical effect of ezetimibe/ simvastatin and ginger root extract on hyperlipidemia and diabetes mellitus induced experimentally in rats
}

\author{
Omnia, M. Abd El-Hamid ${ }^{1}$, Ragab, M. El-Shawarby ${ }^{2}$ and Nanees, A. Abd-Elsamad ${ }^{1}$ \\ Biochemistry Department, Faculty of Vet. Med., Benha University, Egypt. \\ Forensic Medicine and Toxicology Department, Faculty of Vet. Med., Benha University, Egypt.
}

\section{A B S T R A C T}

The present study was aimed to explore the biochemical effect Ezetimibe/ Simvastatin and Ginger in hyperlipidemic and diabetic male albino rats induced by feeding rats high-fat diet for 4-weeks with intraperitoneal injection of a single low dose of streptozotocin $(50 \mathrm{mg} / \mathrm{kg})$ to explore the glycemic condition, lipids and lipoproteins profile, hormones, oxidative stress and antioxidant status. Sixty male albino rats were divided into four groups (15 rats each). Group I: Normal control rats fed on normal ration, received no drugs. Group II: Hyperlipidemic and Diabetic rats, received no drugs and act as ${ }^{+}$ve control .Group III: Hyperlipidemic and Diabetic rats treated with Ezetimibe/Simvastatin at a dose of 1.8 $\mathrm{mg} / \mathrm{kg} / \mathrm{b}$.w/day orally for 4 weeks. Group IV: Hyperlipidemic and Diabetic rats treated with ginger root aqueous extract at a dose of $400 \mathrm{mg} / \mathrm{kg} / \mathrm{b}$.w/day orally for 4 weeks. The obtained results revealed that hyperlipidemic and diabetic rats showing highly significant increase in plasma glucose level, Total cholesterol (TC), Triacylglycerol (TG), Low-density lipoproteins (LDL-C), Very low density lipoprotein (VLDL-C), insulin, insulin resistance (IR), insulin receptor, leptin and L-Malondialdehyde, (L-MDA). On the other hand, plasma High-density lipoprotein-cholesterol (HDL-C) and Total antioxidant capacity (TAC) were showed a different behavioral pattern, where it was detectably significant decrease. Treatment with Ezetimibe/Simvastatin and administration of ginger root extract improved glucose levels, oxidative stress, and insulin resistance and exert antioxidant properties beside its anti-hyperlipidemic activity.

Keywords: Diabetes mellitus, hyperlipidemia, oxidative stress, insulin resistance.

(http://www.bvmj.bu.edu.eg)

(BVMJ-28(1): 53-66, 2015)

\section{INTRODUCTION}

P iabetes mellitus arises when insufficient Insulin is produced or when the available insulin does not function correctly (Garg et al., 2014). Without insulin, the amount of glucose in the blood stream is abnormally high, causing unquenchable thirst and frequent urination. The body's inability to store or use glucose causes hunger and weight loss (Aziz et al., 2013). Hyperlipidemia is a known complication of diabetes mellitus (Shew et al., 2001). Hyperlipidemia, also known as hyperlipoproteinemia, refers to the excess status of fatty substances including cholesterol, triglycerides or lipoproteins in the blood stream (Jang et al.,
2012). Indeed, Patients with non-insulindependent diabetes mellitus (NIDDM) are twice as likely to be hyperlipidemic as nondiabetic subjects (Stewart et al., 1993). Ezetimibe is the first agent of a novel class of selective cholesterol absorption inhibitors and can be applied alone or in combination with statins (Okada et al., 2010). Statins, including simvastatin is an HMG-CoA (3-hydroxy- 3methyglutaryl coenzyme A) reductase inhibitors has been shown to be an effective lipid-lowering agents (Jialal et al., 2001). The single product of ezetimibe/ simvastatin provides superior LDL-C lowering efficacy with improved LDL-C goal attainment (Grigore 
et al., 2008). Zingiber officinale Roscoe (family, Zingiberaceae), known universally as Ginger, is commonly used as a spice and food as well as medicinal agent in Indian, Asian and Arabic traditional medicine in the form of a fresh paste, dried powder, candy (crystallized ginger) or slices preserved in syrup (Račková et al., 2013) The medicinal properties attributed to ginger include hypolipidaemic, hypocholesterolaemic (Furhman et al., 2000 and Bhandari et al., 2005). The experimental model selected to test the biochemical effect of the ezetimibe/ simvastatin, ginger root extract in the present study was high fat diet (HFD) fed rat model followed by a low dose streptozotocin (STZ) injection. Previous studies have reported that the rats fed with HFD are already mildly hyperglycemic and more susceptible to develop significant hyperglycemia and hyperlipidemia with low doses of STZ, which mimics the human type-2 diabetes (Bansal et al., 2012).

\section{2-MATERIALS AND METHOD}

\subsection{Experimental animals:}

Sixty white male albino rats, 12-16 weeks old and average body weight 125-160 gm were used in the experimental investigation of this study. Rats were kept at constant environmental and nutritional conditions throughout the period of experiment. The animals were left 14 days for acclimatization before the beginning of the experiment.

\subsection{Chemicals and Drug:}

Streptozotocin (STZ): Streptozotocin (STZ), N-(1-Naphthyl) ethylenediaminedihydrochloride (NEDD) were purchased from Sigma- Aldrich, USA. All other chemicals were of the highest commercially available grade. Ezetimibe / Simvastatin: It is obtained as Zocozet10/10 drug (one tablet contains Ezetimibe 10mg /Simvastatin $10 \mathrm{mg}$ ). It was manufactured by Marcyl for pharmaceutical industries-ELobour city-Egypt. It was given orally in a daily dose of $1.8 \mathrm{mg} / \mathrm{kg}$ body weight of rat, calculated by extrapolation from the human dose (20 mg/day) as described by Ghosh, (2005). Ginger (Zingiber officinale): Ginger roots powder were purchased from local market. Ginger aqueous extract was given orally in a daily dose of $400 \mathrm{mg} / \mathrm{kg}$ body weight of rat according to (Elrokh et al., 2010). For the preparation of aqueous ginger infusion, $3 \mathrm{~g}$ of ginger powder was dissolved in $100 \mathrm{~mL}$ hot-distilled water and left until it was used.

\subsection{Experimental design:}

Induction of hyperlipidemic and Diabeteic:

After acclimatization, all animals except the normal control were allowed free access to the high-fat diet, described by (Ahmida and Abuzogaya, 2009). After 4 weeks of HFD administration, overnight-fasted $(12 \mathrm{~h})$ rats were administered a single injection of freshly prepared STZ at a dose of $50 \mathrm{mg} / \mathrm{kg} / \mathrm{b} . \mathrm{w}$, which dissolved in citrate buffer at PH 4.2 according to (Ramanthan et al., 1999). After $72 \mathrm{~h}$, STZ-treated rats were fasted for 12 hours, and blood samples were collected from the orbital venous sinus for glucose determination. Rats in hyperlipidemic and diabetic group with blood cholesterol above $150 \mathrm{mg} / \mathrm{dl}$ and glucose levels higher than $250 \mathrm{mg} / \mathrm{dl}$ were considered hyperlipidemic and diabetic .

\section{Animal grouping:}

Rats were randomly divided into four groups (15, each). Group I: Normal control rats fed on normal ration, received no drugs. GroupII: Hyperlipidemic and Diabetic rats, received no drugs and act as control. Group III: Hyperlipidemic and Diabetic rats treated with Ezetimibe /Simvastatin at a dose of $1.8 \mathrm{mg} / \mathrm{kg} / \mathrm{b} . \mathrm{w} /$ day orally for 4 weeks. Group IV: Hyperlipidemic and Diabetic rats treated with ginger root aqueous extract at a dose of (400 $\mathrm{mg} / \mathrm{kg} / \mathrm{b}$.w/day orally for 4 weeks.

\section{Sampling:}

Blood samples were collected from all animals group at 2 and 4 weeks after treatment with Ezetimibe /Simvastatin and 
administration of ginger root extract in the morning following over night fasting from medial canthus of the eyes on EDTA for separation of plasma for estimation glucose (Tietz, 1995); Total cholesterol, (Ellefson and Caraway, 1976); Triacylglycerols,( Stein, 1987); HDL-C, (Finley et al., 1978) LDL-C, (Friedewald et al., 1972); VLDLC, (Bauer, 1982); Insulin, (Wilson and Miles, 1977); Insulin resistance, (Maehata et al.,2002); Insulin receptors (Obata et al., 2007) ; leptin,( Ma et al.,1996) ; L-MDA , (Okhawa et al., 1979); total antioxidant capacity, (Koracevic et al., 2001).

\subsection{Statistical analysis:}

The Statistical analysis was carried out using ANOVA with two factors under significance level of 0.05 for the whole results using SPSS (ver. 19). Data were treated as complete randomization design according to Steel et al., (1997).

\section{RESULTS}

The obtained results presented in table (1) showed significant increase in plasma glucose, TC, TG, LDL-C and VLDL-C with significant decrease in HDL-C levels in hyperlipidemic and diabetic rats all over the periods of the experiments when compared to normal control. In contrast, treated hyperlipidemic and diabetic rats with Ezetimibe/simvastatin and ginger root extract showed significant decrease in plasma glucose, TC, TG, LDL-C and VLDL-C with significant increase in HDL$\mathrm{C}$ levels. The obtained results presented in table (2) showed significant increase in plasma insulin levels insulin resistance, insulin receptors, leptin and LMDA while TAC significant decrease in hyperlipidemic and diabetic rats all over the periods of the experiments when compared to normal control. On the other hand, there are a significant decrease in plasma insulin levels, insulin resistance, insulin receptors, leptin and L-MDA while TAC significant increase as results of treatment hyperlipidemic and diabetic rats with
Ezetimibe /Simvastatin and ginger root extract.

\section{DISCUSSION}

The data recorded in table (1) revealed a significant increase in plasma glucose concentration in hyperlipidemic and diabetic rats group. These results are nearly similar to those reported by Ishak et al., (2013) who demonstrated that plasma glucose level was significantly increased in high fat diet (HFD) and low dose streptozotocin induced diabetes in rats. The hyperglycemia observed in our study could be explained through glucose-fatty acid cycle (Randle et al.,1963), where the high free fat acid (FFA) reduce the glucose uptake and utilization, through the increased endogenous glucose production (Song et al., 2002). Furthermore, STZ causes destruction of pancreatic $\beta$-cells and it makes the cells less active to be sensitive enough towards insulin for glucose uptake and this will cause high glucose concentration in blood (Poitout and Robertson, 2002). Treatment with Ezetimibe/simvastatin to hyperlipidemic and diabetic rats showed significant decrease in plasma glucose levels, These results are nearly similar to those recorded by Mohamadin et al., (2011) and AlJuhaishi et al., (2014) whom found that administration of simvastatin and ezetimibe significantly decreased blood glucose level in diabetic rat. With regard to human studies, Hildemann et al., (2007) reported that, in patients with Type 2 Diabetes mellitus, combination therapy Ezetimibe /simvastatin is usually required to optimize glucose metabolism as well as to help patients achieve aggressive targets for LDL cholesterol and other lipid parameters associated with cardiovascular risk. Statin therapy had beneficial effect on glucose metabolism (Okada et al., 2005). This effect may be associated with the statins' insulinlike activation of a series of kinase cascades that involve PIK3 (phosphatidylinositol 3kinase) and Akt, thus facilitating glucose 
Table (1): Effect of Ezetimibe/simvastatin and ginger root extract administration on plasma glucose, lipid and lipoprotein profile in hyperlipidemia and diabetes induced experimentally in rats.

\begin{tabular}{|c|c|c|c|c|c|c|c|c|c|c|c|c|}
\hline \multirow{2}{*}{$\begin{array}{l}\text { Parameters } \\
\text { Animal } \\
\text { groups }\end{array}$} & \multicolumn{2}{|c|}{ Glucose (mg/dI) } & \multicolumn{2}{|c|}{$\begin{array}{c}\text { Total } \\
\text { cholesterol } \\
(\mathrm{mg} / \mathrm{dI})\end{array}$} & \multicolumn{2}{|c|}{$\begin{array}{c}\mathrm{TG} \\
(\mathrm{mg} / \mathrm{dI})\end{array}$} & \multicolumn{2}{|c|}{$\begin{array}{l}\mathrm{HDL}-\mathrm{c} \\
(\mathrm{mg} / \mathrm{dI})\end{array}$} & \multicolumn{2}{|c|}{$\begin{array}{l}\text { LDL-c } \\
(\mathrm{mg} / \mathrm{dI})\end{array}$} & \multicolumn{2}{|c|}{$\begin{array}{l}\text { VLDL-c } \\
(\mathrm{mg} / \mathrm{dl})\end{array}$} \\
\hline & $\begin{array}{l}\text { After } \\
\text { 2weeks }\end{array}$ & $\begin{array}{c}\text { After } \\
4 \text { week } \\
\text { s }\end{array}$ & $\begin{array}{c}\text { After } \\
2 \text { week } \\
\text { s }\end{array}$ & $\begin{array}{c}\text { After } \\
\text { 4week } \\
\text { s }\end{array}$ & $\begin{array}{c}\text { After } \\
2 \text { week } \\
\text { s }\end{array}$ & $\begin{array}{c}\text { After } \\
4 \text { week } \\
\text { s }\end{array}$ & $\begin{array}{c}\text { After } \\
2 \text { week } \\
\text { s }\end{array}$ & $\begin{array}{c}\text { After } \\
4 \text { week } \\
\text { s }\end{array}$ & $\begin{array}{c}\text { After } \\
\text { 2weeks }\end{array}$ & $\begin{array}{c}\text { After } \\
\text { 4weeks }\end{array}$ & $\begin{array}{c}\text { After } \\
\text { 2weeks }\end{array}$ & $\begin{array}{c}\text { After } \\
4 \text { week } \\
\text { s }\end{array}$ \\
\hline Normal & $\begin{array}{l}107.25 \\
\pm 5.15^{\mathrm{a}}\end{array}$ & $\begin{array}{l}99.54 \\
\pm 2.85^{\mathrm{a}}\end{array}$ & $\begin{array}{c}121.8 \\
2 \pm 3.9 \\
4^{\mathrm{a}}\end{array}$ & $\begin{array}{c}122.0 \\
3 \pm 2.5 \\
9^{\mathrm{b}}\end{array}$ & $\begin{array}{c}104.8 \\
4 \pm 9.4 \\
4^{b}\end{array}$ & $\begin{array}{c}119.9 \\
4 \pm 2.7 \\
0^{\mathrm{c}}\end{array}$ & $\begin{array}{l}56.90 \\
\pm 1.45^{\mathrm{b}}\end{array}$ & $\begin{array}{l}57.13 \\
\pm 2.67^{\mathrm{b}}\end{array}$ & $\begin{array}{l}43.96 \\
\pm 3.46^{\mathrm{a}}\end{array}$ & $\begin{array}{l}40.91 \\
\pm 4.56^{\mathrm{b}}\end{array}$ & $\begin{array}{c}20.97 \\
\pm 1.88^{\mathrm{b}}\end{array}$ & $\begin{array}{r}23.99 \\
\pm 0.54^{\mathrm{c}}\end{array}$ \\
\hline $\begin{array}{c}\text { Diabetes - } \\
\text { Hyperlipidemia }\end{array}$ & $\begin{array}{l}384.45 \\
\pm 9.66^{\mathrm{d}}\end{array}$ & $\begin{array}{c}507.5 \\
6 \pm 9.7 \\
9^{d}\end{array}$ & $\begin{array}{c}216.8 \\
4 \pm 2.2 \\
1^{\mathrm{c}}\end{array}$ & $\begin{array}{c}265.4 \\
7 \pm 2.0 \\
5^{\mathrm{c}}\end{array}$ & $\begin{array}{c}294.9 \\
2 \pm 6.8 \\
1^{\mathrm{c}}\end{array}$ & $\begin{array}{c}385.4 \\
4 \pm 5.1 \\
4^{\mathrm{d}}\end{array}$ & $\begin{array}{c}39.03 \\
\pm 0.64^{\mathrm{a}}\end{array}$ & $\begin{array}{l}36.32 \\
\pm 2.35^{\mathrm{a}}\end{array}$ & $\begin{array}{l}98.82 \\
\pm 3.95^{\mathrm{c}}\end{array}$ & $\begin{array}{l}151.95 \\
\pm 1.81^{\mathrm{c}}\end{array}$ & $\begin{array}{l}58.98 \\
\pm 1.37^{\mathrm{c}}\end{array}$ & $\begin{array}{r}77.09 \\
\pm 1.03^{\mathrm{d}}\end{array}$ \\
\hline $\begin{array}{l}\text { Ezetimibe - } \\
\text { Simvastatin }\end{array}$ & $\begin{array}{l}233.42 \\
\pm 31.71^{\mathrm{c}}\end{array}$ & $\begin{array}{c}179.6 \\
4 \pm 11 . \\
08^{c}\end{array}$ & $\begin{array}{c}130.6 \\
7 \pm 5.6 \\
7^{\mathrm{b}}\end{array}$ & $\begin{array}{c}109.6 \\
9 \pm 3.1 \\
3^{\mathrm{a}}\end{array}$ & $\begin{array}{c}106.0 \\
9 \pm 6.6 \\
9^{b}\end{array}$ & $\begin{array}{l}76.57 \\
\pm 3.95^{\mathrm{a}}\end{array}$ & $\begin{array}{c}57.24 \\
\pm 1.39^{\mathrm{b}}\end{array}$ & $\begin{array}{l}59.77 \\
\pm 1.20^{\mathrm{b}}\end{array}$ & $\begin{array}{c}52.17 \\
\pm 5.03^{\mathrm{b}}\end{array}$ & $\begin{array}{c}34.60 \\
\pm 2.36^{\mathrm{ab}}\end{array}$ & $\begin{array}{c}21.26 \\
\pm 1.34^{\mathrm{b}}\end{array}$ & $\begin{array}{c}77.09 \\
\pm 1.03^{\mathrm{d}}\end{array}$ \\
\hline Ginger & $\begin{array}{l}144.57 \\
\pm 5.47^{b}\end{array}$ & $\begin{array}{c}163.4 \\
8 \pm 6.7 \\
4^{b}\end{array}$ & $\begin{array}{c}123.1 \\
3 \pm 1.1 \\
3^{\mathrm{ab}}\end{array}$ & $\begin{array}{c}114.4 \\
2 \pm 5.1 \\
9^{\mathrm{a}}\end{array}$ & $\begin{array}{l}76.37 \\
\pm 6.89^{\mathrm{a}}\end{array}$ & $\begin{array}{l}97.14 \\
\pm 6.00^{\mathrm{b}}\end{array}$ & $\begin{array}{r}59.31 \\
\pm 2.34^{\mathrm{b}}\end{array}$ & $\begin{array}{l}65.95 \\
\pm 4.05^{\mathrm{c}}\end{array}$ & $\begin{array}{c}48.54 \\
\pm 3.41^{\mathrm{ab}}\end{array}$ & $\begin{array}{l}29.00 \\
\pm 1.92^{\mathrm{a}}\end{array}$ & $\begin{array}{l}15.27 \\
\pm 1.38^{\mathrm{a}}\end{array}$ & $\begin{array}{c}19.43 \\
\pm 1.20^{\mathrm{b}}\end{array}$ \\
\hline
\end{tabular}

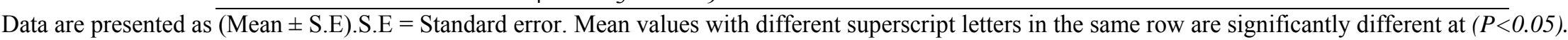

Table (2): Effect of Ezetimibe/simvastatin and ginger root extract administration on levels plasma insulin, insulin resistance, insulin receptors, leptin, L-MDA and TAC in hyperlipidemia and diabetes induced experimentally in rats.

\begin{tabular}{|c|c|c|c|c|c|c|c|c|c|c|c|c|}
\hline \multirow{2}{*}{$\begin{array}{l}\text { Parameters } \\
\text { Animal } \\
\text { groups }\end{array}$} & \multicolumn{2}{|c|}{$\begin{array}{c}\text { Insulin } \\
(\mathrm{MIu} / \mathrm{ml})\end{array}$} & \multicolumn{2}{|c|}{ Insulin resistance } & \multicolumn{2}{|c|}{$\begin{array}{l}\text { insulin receptors } \\
(\mathrm{ng} / \mathrm{ml})\end{array}$} & \multicolumn{2}{|c|}{$\begin{array}{c}\text { leptin } \\
\text { (ng/ml) }\end{array}$} & \multicolumn{2}{|c|}{$\begin{array}{c}\text { MDA } \\
(\mathrm{Mmol} / \mathrm{I})\end{array}$} & \multicolumn{2}{|c|}{$\begin{array}{l}\text { TAC } \\
(\mathrm{u} / \mathrm{I})\end{array}$} \\
\hline & $\begin{array}{c}\text { After } \\
\text { 2weeks }\end{array}$ & $\begin{array}{c}\text { After } \\
\text { 4weeks }\end{array}$ & $\begin{array}{c}\text { After } \\
\text { 2weeks }\end{array}$ & $\begin{array}{c}\text { After } \\
\text { 4weeks }\end{array}$ & $\begin{array}{c}\text { After } \\
\text { 2weeks }\end{array}$ & $\begin{array}{c}\text { After } \\
\text { 4weeks }\end{array}$ & $\begin{array}{c}\text { After } \\
\text { 2weeks }\end{array}$ & $\begin{array}{c}\text { After } \\
\text { 4weeks }\end{array}$ & $\begin{array}{c}\text { After } \\
\text { 2weeks }\end{array}$ & $\begin{array}{c}\text { After } \\
\text { 4weeks }\end{array}$ & $\begin{array}{c}\text { After } \\
\text { 2weeks }\end{array}$ & $\begin{array}{c}\text { After } \\
\text { 4weeks }\end{array}$ \\
\hline Normal & $\begin{array}{c}8.17 \\
\pm 0.55^{\mathrm{a}}\end{array}$ & $\begin{array}{c}8.17 \\
\pm 0.41^{\mathrm{a}}\end{array}$ & $\begin{array}{c}2.07 \\
\pm 0.18^{\mathrm{a}}\end{array}$ & $\begin{array}{c}2.01 \\
\pm 0.11^{\mathrm{a}}\end{array}$ & $\begin{array}{c}1.92 \\
\pm 0.06^{\mathrm{a}}\end{array}$ & $\begin{array}{c}2.15 \\
\pm 0.07^{\mathrm{a}}\end{array}$ & $\begin{array}{c}2.28 \\
\pm 0.11^{\mathrm{a}}\end{array}$ & $\begin{array}{c}2.28 \\
\pm 0.11^{\mathrm{a}}\end{array}$ & $\begin{array}{l}103.71 \\
\pm 6.16^{\mathrm{c}}\end{array}$ & $\begin{array}{l}104.24 \\
\pm 1.72^{\mathrm{c}}\end{array}$ & $\begin{array}{c}6.47 \\
\pm 0.62^{\mathrm{c}}\end{array}$ & $\begin{array}{c}6.45 \\
\pm 0.63^{\mathrm{c}}\end{array}$ \\
\hline $\begin{array}{l}\text { Diabetes- } \\
\text { Hyperlipidemia }\end{array}$ & $\begin{array}{l}16.05 \\
\pm 0.27^{\mathrm{c}}\end{array}$ & $\begin{array}{c}15.3 \\
\pm 1.42^{\mathrm{b}}\end{array}$ & $\begin{array}{c}15.22 \\
\pm 0.19^{c}\end{array}$ & $\begin{array}{l}19.10 \\
\pm 1.55^{\mathrm{c}}\end{array}$ & $\begin{array}{c}3.39 \\
\pm 0.14^{\mathrm{c}}\end{array}$ & $\begin{array}{c}3.32 \\
\pm 0.11^{\mathrm{c}}\end{array}$ & $\begin{array}{c}3.59 \\
\pm 0.25^{\mathrm{b}}\end{array}$ & $\begin{array}{c}3.59 \\
\pm 0.25^{\mathrm{b}}\end{array}$ & $\begin{array}{l}154.42 \\
\pm 9.41^{\mathrm{d}}\end{array}$ & $\begin{array}{c}150.33 \\
\pm 10.46^{\mathrm{d}}\end{array}$ & $\begin{array}{c}2.78 \\
\pm 0.26^{\mathrm{a}}\end{array}$ & $\begin{array}{c}2.26 \\
\pm 0.46^{\mathrm{a}}\end{array}$ \\
\hline $\begin{array}{l}\text { Ezetimibe - } \\
\text { Simvastatin }\end{array}$ & $\begin{array}{c}11.43 \\
\pm 0.15^{\mathrm{b}}\end{array}$ & $\begin{array}{c}9.78 \\
\pm 0.26^{\mathrm{a}}\end{array}$ & $\begin{array}{c}6.53 \\
\pm 0.93^{\mathrm{b}}\end{array}$ & $\begin{array}{c}4.30 \\
\pm 0.18^{\mathrm{b}}\end{array}$ & $\begin{array}{c}2.50 \\
\pm 0.12^{\mathrm{b}}\end{array}$ & $\begin{array}{c}2.29 \\
\pm 0.08^{\mathrm{a}}\end{array}$ & $\begin{array}{c}2.31 \\
\pm 0.13^{\mathrm{a}}\end{array}$ & $\begin{array}{c}2.31 \\
\pm 0.13^{\mathrm{a}}\end{array}$ & $\begin{array}{l}90.28 \\
\pm 4.54^{\mathrm{b}}\end{array}$ & $\begin{array}{c}82.54 \\
\pm 1.88^{\mathrm{b}}\end{array}$ & $\begin{array}{c}3.91 \\
\pm 0.25^{\mathrm{b}}\end{array}$ & $\begin{array}{c}4.61 \\
\pm 0.21^{\mathrm{b}}\end{array}$ \\
\hline Ginger & $\begin{array}{c}8.19 \\
\pm 0.55^{\mathrm{a}} \\
\end{array}$ & $\begin{array}{r}8.19 \\
\pm 0.44^{\mathrm{a}} \\
\end{array}$ & $\begin{array}{c}2.81 \\
\pm 0.13^{\mathrm{a}} \\
\end{array}$ & $\begin{array}{c}3.31 \\
\pm 0.25^{\mathrm{a}} \\
\end{array}$ & $\begin{array}{c}2.54 \\
\pm 0.08^{\mathrm{b}} \\
\end{array}$ & $\begin{array}{c}2.52 \\
\pm 0.09^{\mathrm{b}} \\
\end{array}$ & $\begin{array}{c}2.13 \\
\pm 0.12^{\mathrm{a}} \\
\end{array}$ & $\begin{array}{c}2.13 \\
\pm 0.12^{\mathrm{a}} \\
\end{array}$ & $\begin{array}{r}68.06 \\
\pm 3.42^{\mathrm{a}} \\
\end{array}$ & $\begin{array}{r}68.70 \\
\pm 3.52^{\mathrm{a}} \\
\end{array}$ & $\begin{array}{c}6.38 \\
\pm 0.64^{\mathrm{c}} \\
\end{array}$ & $\begin{array}{c}7.44 \\
\pm 0.42^{\mathrm{c}} \\
\end{array}$ \\
\hline
\end{tabular}


uptake (Le Roith and Zick, 2001). In same manner, ezetimibe may promote the phosphorylation of PI-3K /AKT via suppressing the hepatic Niemann-Pick C1 Like 1 (NPC1L1) activity an inhibit the JNK (c-Jun N-terminal kinase) activity ,which then improves the insulin resistance (Zhong et al., 2012) and reduce blood glucose. Administration of ginger to hyperlipidemic and diabetic rats showed significant decrease in plasma glucose levels, These results are nearly similar to those recorded by Al-Azhary et al., (2011) who revealed that the oral administration of ginger extract with daily dose of $25 \mathrm{mg} / \mathrm{Kg}$ for 6 weeks produced a decline in blood glucose in diabetic cholesterol- fed rats. Many investigators reported that compounds of ginger such as 6-gingerol, tannins, polyphenolic compounds, flavonoids, and triterpenoids of possess hypoglycemic and other pharmacological properties (Khandouzi et al., 2015). Moreover, Rani et al., (2011) suggested that ginger, via its major component, gingerol, by inhibition of key enzymes relevant to type 2 diabetes, $\alpha$ glucosidase and $\alpha$-amylase, are known to improve diabetes. In addition, It has been reported that an infusion of 6-gingerol in a dose dependent inhibits blood glucose absorption from the gut (Jafri et al., 2011). Another explanation, Ginger extracts may act by increasing peripheral utilization and inhibition of the proximal tubular re absorption mechanism for glucose in the kidney, which have a glucose lowering effect (Subramanian et al., 1996). The data represented in table (1) showed significant increase in plasmaTC, TG, LDL-C and VLDL-C with significant decrease in HDL$\mathrm{C}$ levels in hyperlipidemic and diabetic rats. These results are in agreement with Ansarullah et al., (2012) who reported that in normal condition, insulin increases the receptor-mediated removal of LDLcholesterol and the decreased activity of insulin in diabetes causes hypercholesterolemia. Elevated TG and TC levels may also be attributed to increased absorption and formation of TG following exogenous consumption of HFD or reduced TG uptake in peripheral tissues (Srinivasan et al., 2005), resulting in secondary abnormalities of low HDL-C and increased LDL-C (Taskinen, 2003).Furthermore, Hypercholesterolemia in STZ-induced diabetic rats may be due to increased intestinal absorption and synthesis of cholesterol (Mathe, 1995). In addition, (Babu and Srinivasan, 1997) suggested that the increase in circulatory VLDL and their associated triglycerides may be due to due to defective clearance of these particles from the circulation. The data recorded in table (1) revealed significant decrease in plasma TC, TG, LDL-C and VLDL-C levels with significant increase in HDL-C after treatment with Ezetimibe /simvastatin to hyperlipidemic and diabetic rats .These results are in agreement with These results are in agreement with Samaha et al., (2013) who reported that, the addition of ezetimibe to simvastatin significantly decreased TC and produced further lowering of LDL-C of around $20 \%$ and had a more favorable effect on HDL-C and triglycerides in stz- induced diabetic rats . Ezetimibe with block of sterol transporter Niemann-Pick C1-like 1 (NPC1L1) protein inhibits absorption of cholesterol up to $96 \%$ in animal models and nearly $50 \%$ in patients with mild hypercholesterolemia (Domagala et al., 2003). The hypocholesterolemic potency of simvastatin is mainly mediated via inhibition of HMG-CoA reductase activity, the rate-limiting step in cholesterol biosynthesis (Kenis et al., 2005). The data represented in table (1) revealed significant decrease in the levels of plasmaTC, TG, LDL-C and VLDL-C with significant decrease in HDL-C levels aftera dministration of ginger to hyperlipidemic and diabetic rats . These results came in accordance with Al-Noory et al.,(2013) who found that administration of ginger $(500 \mathrm{mg} / \mathrm{kg} . \mathrm{b} . \mathrm{w})$ to diabetic rats reduced plasma TC,TG and LDL levels whereas HDL levels significant increased when compared to diabetic control group. The plasma lipid lowering effect of ginger is 
possibly associated with several processes, including disruption of cholesterol absorption from the GI tract and interference with cholesterol biosynthesis in liver Several lines of evidence revealed that ginger contains antioxidant properties which have a hypocholesterolemic effect and anti-atherogenic, and these activities might be attributed to the inhibition of LDL oxidation and the suppression on the activity of HMG-CoA (3-hydroxy3 methyglutaryl co-enzyme A) reductase .This also might occur due to the elevation of hepatic cholesterol 7-alpha-hydroxylase activity, which is a rate-limiting enzyme in the biosynthesis of the bile acids and stimulates the conversion of cholesterol to bile acids leading to the excretion of cholesterol from the body (Paul et al., 2012). Hyperlipidemic and Diabetic rats showed a significant increase in plasma insulin levels and Insulin resistance numerically high. These results are in agreement with Bas et al., (2012) found that the plasma insulin concentration significantly increased and insulin resistance was numerically higher in diabetes rats induced by intraperitoneal injection of streptozotocin $(35 \mathrm{mg} / \mathrm{kg} \mathrm{bw})$ in rats after being fed for 2 weeks high-fat diet. High-fat-diet with low dose of streptozotocin that are used for the induction of T2DM animal model are characterized by abnormal metabolism of carbohydrates, fats and proteins, which is attributable to decreased insulin sensitivity leading to insulin resistance (Fang et al., 2013). Also, STZ caused rapid destruction of pancreatic $\beta$-cells in rats, which led to impaired glucose stimulated insulin release and insulin resistance, both of which are marked features of T2DM ( Farswan et al., 2009) . Furthermore, Hyperglycemia has been shown to generate free radicals from auto-oxidation of glucose (Inoguchi et al.,2000), high level of free radicals and the simultaneous decline in antioxidant defense mechanisms may lead to the damage of cellular organelles and enzymes, increased lipid peroxidation and development of insulin resistance ( El Naggar et al., 2005). The data represented in table (2) revealed significant decrease in plasma insulin levels and insulin resistance in hyperlipidemic and diabetic rats treated with Ezetimibe /Simvastatin which might be due to lowering lipid levels, previous studies showing a negative correlation between a generally more favorable lipid profile and insulin resistance (Al-Azzam et al., 2013). Another explanation, statins inhibit the glucose-induced elevation of free $\left[\mathrm{Ca}^{+2}\right]$ in cytoplasm, thereby diminishing insulin secretion (Szendroedi et al., 2009) which might be reason for decrease plasma insulin concentrations. Furthermore, Clinical studies have been reported that ezetimibe improves insulin resistance in animals (Deushi et al.,2007) and humans (Tsunoda et al., 2013) and the positive effect of statins on insulin sensitivity in type 2 diabetic subjects(Hydrie et al., 2007). The data in table (2) revealed significant decrease in plasma insulin levels and insulin resistance after administration of ginger to hyperlipidemic and diabetic rats. These results are in agreement with Iranloye et al., (2011) reported that ginger effectively reduced fasting blood glucose and malonydealdehyde levels and insulin resistant in diabetic rats compared to control and ginger only treated rats. Several studies stated that ginger have permanent effects of reducing lipids, and accordingly, increases insulin sensitivity. Owing to some studies showed that increasing the level of plasma free fatty acids (FFAs) lead to insulin resistance, ginger indicate anti-insulin resistance effects by reducing the level of plasma FFAs (Li et al.,2012).Another reason, may due to ginger has many antioxidant compounds; these compounds may either mitigate or prevent generation of free radicals in toxic conditions (Dugasani et al., 2010). The presence of a plasma Soluble Insulin Receptor (SIR) is a phenomenon that has been previously associated with insulin resistance in T2DM in humans and animal models (Hiriart et al., 
2014). The data recorded in table (2) revealed a significant increase in plasma insulin receptor levels in hyperlipidemic and diabetic rats. These results are similar to Hiriart et al., (2014) who inducted that the level of SIR in the plasma of metabolic syndrome rats was twofold higher than in controls, which might due to the insulin hyper secretion developed by these animals. Another study was done by, Yuasa et al., (2014) observed that several cells release more SIR when stimulated with high glucose concentrations, indicating that this process can also be exacerbated in conditions that mimic diabetes mellitus.

Hyperlipidemia has also been reported as one of the causative factors for increased lipid peroxidation in diabetes (Kesavulu et al., 2002), lipid peroxides leading to decrease in membrane permeability, changes in membrane integrity could be responsible for the decreased number of receptor site per cell (Pari et al., 2007) .Thereby, treatment with Ezetimibe /Simvastatin to hyperlipidemic and diabetic rats showed significant decreased in plasma insulin receptors, which may due to greater improvements the lipid profile. Another explanation, may due to with adverse effects of Ezetimibe/Simvastatin on insulin resistance and decreased insulin level (Hiramitsu et al., 2010 , Hydrie et al., 2007 and Moutzouri et al.,2011). Several cell lines, including the human hepatoma HepG2 cells, have been described to release IRs when facing high concentrations of insulin (Papa et al., 1993). The data represented in table (2) showed significant decrease in plasma insulin receptors after administration of ginger root extract to hyperlipidemic and diabetic rats and that might be due to the great hypolipidemic effects of ginger in diabetic rats which improves insulin resistance (Li et al., 2012). Hence, SIR levels were positively correlated with fasting plasma insulin (El Mesallamy et al., 2013). Another possible mechanism for the reduction of plasma insulin receptors concentration is inhibition of proteinase activity by ginger (Thakur,
2013). Proteinase inhibitors have the ability to decrease insulin- dependent receptor release and proteolysis from plasma membranes in IM-9 cells (Papa et al., 1993) and hepatocytes, it has been proposed that insulin promotes the activity of a proteinase that mediates the release of IRs from hepatocytes (Sanchez-Casas et al., 1995). Recent studies have shown that leptin has peripheral actions to stimulate vascular inflammation, oxidative stress and vascular smooth muscle hypertrophy that may contribute to pathogenesis of T2DM hypertension, atherosclerosis and coronary heart disease (Ajala et al., 2009). The data represented in table (2) revealed a significant increase of plasma leptin concentration in hyperlipidemic and diabetic rats. These results agree with Bas et al., (2012) who found that significantly increased of leptin levels in diabetes rats induced by fed rats for 2 weeks high-fat diet and then intraperitoneal injected of streptozotocin (35 mg/kg bw) . These results may due to in streptozotocin- and high-carbohydrate/high-fat diet-induced diabetic rats, diabetic rats had much higher blood insulin level than that of the control ones (Zhou et al., 2009), the elevated insulin level in T2DM stimulates leptin expression/ release (Al-Tu'ma et al., 2011). The data represented in table (2) revealed significant decrease in plasma leptin after treated hyperlipidemic and diabetic rats with Ezetimbie/Simvastatin which could be attributed to its lipid-lowering action, leptin levels were positively correlated with triglyceride, cholesterol and LDL and an inverse relationship was found between leptin and HDL (Zabut et al.,2007). Additionally, simvastatin suppressed leptin expression in 3T3-L1 cells (Maeda and Horiuchi, 2009). Administration of ginger to hyperlipidemic and diabetic rats showed significant decrease in plasma leptin levels, These results may due to gingerol a major chemical component of the ginger rhizome cause decreased in plasma leptin levels (Saravanan et al., 2014) and may also due to ginger behaves like hypocholesterolaemic 
agents, The hypercholesterolemia itself might induce increased serum leptin level (Hang et al., 2012). MDA is being widely used as an indicator of oxidative stress in biological systems (Yagi ,1998). We found the induction of diabetic and hyperlipidemic produced a significant increase in plasma MDA compared to the normal control group, Our present findings are in line with Mahmoud et al.,(2014) who found that there was highly statistical significant increased in plasma MDA level in diabetic induced by fed the rats with high fat diet and injected individually with a dose of $40 \mathrm{mg} / \mathrm{kg}$ by streptozotosin (STZ) when compared to control, which may due to intake of dietary fat directly enhanced reactive oxygen species (ROS )overproduction, which increased lipid peroxidation (Zhang et al. , 2005) and the cytotoxic action of STZ is also associated with the generation of ROS causing oxidative damage (Lenzen, 2008). Data of the present work indicated that Ezetimibe / Simvastatin significantly reduced plasma MDA level in hyperlipidemic and diabetic rats, These results run parallel with Kuzelová et al., (2008) who reported that treatment with simvastatin decreased oxidative stress in diabetichypercholesterolemic rats. According to, Al-Malki et al., (2009) observed that treatment with ezetimibe plus simvastatin resulted in significant lowering in serum MDA levels in dyslipidaemic patient. Although the precise mechanisms of this phenomenon remain unclear, there are some possible explanations, Recently studies suggest that Ezetimibe as a therapy "complementary" to statins remarkably reduced a circulating oxidative stress marker and derivatives of reactive oxidative metabolites (dROMs) in patients with dyslipidemia, probably by decreasing the tendency to peroxidation of LDL and reducing circulating ox-LDL level (Yamaoka-Tojo et al., 2009). Ginger root extract significantly reduced plasma MDA level in hyperlipidemic and diabetic rats, These results run parallel with Al-Azhary et al., (2011) who found that administrated of ginger extract with daily dose of $25 \mathrm{mg} / \mathrm{Kg}$ for 6 weeks resulted in significant reduced in malondialdehyde concentration and significant elevated in total plasma antioxidant activity in diabetic cholesterolfed rats. Decreasing lipid peroxidation by administration of ginger extract may be attributed to ginger ability to low increased lipid parameters, hypertriglyceridemia and hypercholesterolemia were associated with oxidative modification of LDL, protein glycation, glucose-autooxidation, thus leading to excess production of lipid peroxidation products (Yang et al., 2008) and may be attributed to it's antioxidant activity, because ginger have many phenolic compounds, which have inhibitory effects on lipid peroxidation and preserve the antioxidant compounds(Khandouzi et al., 2015).

Total plasma antioxidant capacity (TAC) showed significant decreased in hyperlipidemic and diabetic rats. These results were in harmony with Mahmoud et al.,(2014) who found that, there was significant decreased in plasma total antioxidant capacity in diabetic rats induced by fed the rats with high fat diet and injected individually with a dose of $40 \mathrm{mg} / \mathrm{kg}$ by streptozotosin (STZ). The present study provided a further evidence that HFD/STZinduced hyperglycaemia in rats is accompanied by increased levels of MDA together with suppression in the total antioxidant capacity. This severe depletion of TAC may be explained by the glycemic deregulation in diabetic rats. The modulation of oxidative environments by Ezetimibe / Simvastatin may be a causative link in the observed evaluation of TAC levels in our study, It has been reported that both simvastatin and ezetimibe administration may reduce oxidative stress in diabetes and dyslipidemia (Kater et al. , 2010 and Kostapanos et al., 2011). In addition, Turafaner et al., (2010) reported that ezetimibe significantly increase of TAC levels in patients with hyperlipidemia may be through lowering lipid levels or 
other mechanisms such as decreasing insulin resistance and the pleiotropic effects of the drug. In same manner, Vishal et al., (2005) indicated that some of the cholesterol-independent effects of simvastatin decreasing oxidative stress. In this context, Sobal and Sinzinger, (2005) observed that simvastatin besides its lipid lowering action had also significant antioxidative properties in diabetic patients. Administration of ginger root extract to hyperlipidemic and diabetic rats significant increased the Total plasma antioxidant capacity (TAC) concentrations, These results were in harmony with Al-Assaf, (2012) who reported that the administrated of ginger extract $(0.5 \mathrm{~g} / \mathrm{kg}$ body wt) to STZinduced diabetic rats caused significant decreased in plasma malondialdehyde concentration and significant increase in total antioxidant capacity. These results may due to lowering lipid levels. It is known that hyperlipidemic states are associated with altered physical properties of cellular membranes, which may facilitate the escape of free radicals from the mitochondrial electron transport chain or the activation of NADPH oxidase (Yang et al., 2008). Therefore, from these results we suggest that, Ezetimibe/Simvastatin, Ginger can be a good option for treatment of diabetic patients with concomitant hyperlipidemia.

\section{REFERENCES}

Ahmida,M.H., Abuzogaya, M.H. 2009. The Effects of Oral Administration of Green Tea and Ginger Extracts on Serum and Hepatic Lipid Content in Rats Fed a Hyperlipidemic Diet: Journal of Applied Sciences Research, 5(10): 1709-1713.

Ajala, M.O., Ogunro, P.S., Idogun, S.E., Osundeko, O. 2009. Relationship between Plasma Antioxidant Status and Leptin in Controlled and Non-Controlled Type 2 Diabetic Non-Obese Women. Int $\mathrm{J}$ Endocrinol Metab 4: 214-21.

Al-Assaf, A.H. 2012. Antihyperglycemic and antioxidant effect of ginger extract on streptozotocin-diabetic rats. Paki. J. of Nutri. 11: 1107-1112.
Al-Azhary, D.B. 2011. Ginger Enhances Antioxidant Activity and Attenuates Atherogenesis in Diabetic Cholesterol-Fed Rats: Aust. J. Basic \& Appl. Sci. 5(12): 2150-2158.

Al-Azzam, S.I., Alkhateeb, A.M., Alzoubi, K.H., Alzayadeen, R.N., Ababneh , M.A., Khabour, O.F. 2013. Atorvastatin treatment modulates the interaction between leptin and adiponectin, and the clinical parameters in patients with type II diabetes. Exp Ther Med. (6): 1565-1569.

Al-Juhaishi, A.M.R. 2014. Modulation of hyperglycemia and oxidative stress by Ezetimibe in Sreptozotocin induce diabetes mellitus rats. Kerbala Journal of Pharmaceutical Sciens 7: 42-50.

Al-Malki, F.H., Ali, S.H., Abdulbari, G.A. 2009. Role of Ezetimibe in Combination with Statins (Simvastatin and Atorvastatin) in Controlling Dyslipidemia; Iraqi J Pharm Sci 18(1).

Al-Noory, A.S., Amreen, A., Hymoor, S. 2013. Anti-hyperlipidemic effects of ginger extracts in alloxan-induced diabetes and propylthiouracil- induced hypothyroidism in (rats). Phcog Res 5: 157-61.

Al-Tu'ma, F.J., Yassin, A.G., Al-Kayatt, T.H. 2011. Effects of Type-2 Diabetes Mellitus on Serum Leptin, Insulin, Interlukin-8, and Lipid Profile: Karbala J. Med. 4: 12 .

Ansarullah, B.B., Patel, V., Ramachandran A.V. 2012. Improved glucoregulation, insulin resistance and leptin levels by a polyherbal durg in high fat diet and low dose Streptozotocin Type 2 diabetes model. Diabetologia Croatica 41:1.

Aziz, S.B., Mohialdeen, S.K., Chlimeran, S.K. 2013. Evaluation of lipid profile in patients with type II diabetes mellitus on different treatment: Tikrit Journal of Pharmaceutical Sciences. 9(1):253-261.

Babu, P.S., Srinivasan, K. 1997. Hypolipidaemic action of Curcumin, the active principle of turmeric (Curcuma longa) in streptozotocin induced diabetic rats. Mol Cell Biochem. 166(1-2):169-175.

Bansal, P., Paul, P., Mudgal, J., Nayak, P.G., Pannakal, S.T., Priyadarsini, K.I., Unnikrishnan, M.K. 2012. Antidiabetic, antihyperlipidemic and antioxidant effects of the flavonoid rich fraction of Pilea microphylla L. in high fat diet /streptozotocin-induced diabetes in mice. Exp Toxicol Pathol. 64(6): 651-8. 
Bas, A.L., Demirc, S., Yazihan, N., Uney, K., Kaya, E.E. 2012. Nerium oleander Distillate Improves Fat and Glucose Metabolism in High-Fat Diet-Fed Streptozotocin-Induced Diabetic Rats: International Journal of Endocrinology Article ID 947187, 10.

Bauer, J.D. 1982. "Clinical laboratory methods" 9th Ed, the C.V. Company Waistline Industrial Missouri 63116 Chapter 33, pp 555.

Bhandari, U., kanojia, R., Pillai, K.K. 2005. Effect of ethanol extract of Zingiber officinale on dyslipidemia in diabetic rats. J. Ethanopharmacol. 97: 227-230.

Deushi, M., Nomura, M., Kawakami, A., Haraguchi, M., Ito, M., Okazaki, M., Ishii, H. ,Yoshida, M. 2007. Ezetimibe improves liver steatosis and insulin resistance in obese rat model of metabolic syndrome. FEBS Lett. 581(29): 5664-70.

Domagala, B.M., Pharm, D., Leady, M. 2003. Ezetimibe: The First Cholesterol Absorption Inhibitor, Pharm Spotlight, 28(3): 191-206.

Dugasani, S., Pichika, M.R., Nadarajah, V.D., Balijepalli, M.K., Tandra, S., Korlakunta, J.N. 2010. Comparative antioxidant and anti-inflammatory effects of [6]-gingerol, [8]-gingerol, [10]-gingerol and [6]shogaol. J. Ethnopharmacol. 127:515-520.

El Mesallamy, H.O., Hamdy, N.M., Mostafa, D.M., Amin, A.I. 2013. The serine protease granzyme $\mathrm{b}$ as an inflammatory marker, in relation to the insulin receptor cleavage in human obesity and type 2 diabetes mellitus. J Interferon Cytokine Res .34:179-86.

El Naggar, E.M.B., Bartošíková, L., Žemlička, M., Švajdlenka, E., Rabišková, M., Strnadová, V., Nečas. J. 2005. Antidiabetic effect of Cleome droserifolia aerial parts: Lipid peroxidation-induced oxidative stress in diabetic rats. Acta Vet Brno .74: $347-52$.

Ellefson, R.D., Caraway, W.T. 1976. Fundamentals of clinical chemistry. Ed Tietz NW, pp. 506.

Elrokh, E., Yassin, N.A., El-Shenawy, S.M., Ibrahim, B.M. 2010. Antihypercholesterolaemic effect of ginger rhizome (Zingiber officinale) in rats: Inflammopharmacology. 18(6): 309-15.

Fang, J.G., Wei, H.K., Sun, Y.Y., Zhang, X.D., Liu, W.Y., Chang, Q.T., Wang, R.H.
,Gong, Y.W. 2013. Regulation of podocalyxin expression in the kidney of streptozotocin-induced diabetic rats with Chinese herbs (Yishen capsule).BMC Complement Altern Med .76:1-6.

Farswan ,M., Mazumder, P.M. ,Parcha V. 2009. Modulatory effect of an isolated compound from Syzygium cumini seeds on biochemical parameters of diabetes in rats. Int J Green Pharm. 3:128-33.

Finely, P.R, Schifmou, K.B, Williams, R.J ,Lichti, D.A.1978.Cholesterol in high density lipoproteins: use of $\mathrm{Mg}^{2}+$ destran sulfate in its enzymatic measurement. Clin. Chem. 24, 931-933.

Friedewald, W.T., Levy, R.I. ,Frederickson, D.S. 1972.Estimation of the concentration of low density lipoprotein cholesterol in plasma without use of the preparative ultracentrifuge. Clin Chem.18 (6):499502.

Fuhrman, B., Rosenblat,M., Hayek,T., Coleman,R. ,Aviram,M. 2000. Ginger Extract Consumption Reduces Plasma Cholesterol, Inhibits LDL Oxidation and Attenuates Development of Atherosclerosis in Atherosclerotic, Apolipoprotein E Deficient Mice. J. Nutr., 130: 1124- 3.

Garg, N., YB Agrawal, Y. ,Gupta, S. 2014. A study of lipid profile levels in diabetics and non-diabetics taking TC/HDL ratio and LDL/HDL ratio into consideration. JIACM .15(3-4): 192-5.

Ghosh, M.N. 2005. Guide to drug doses in laboratory animals Fundamentals of experimental Pharmacology 3rd edition, Hiltonand Company, Calcutta. 191-201.

Grigore , L., Norata ,G.D. ,Catapano ,A.L. 2008. Combination therapy in cholesterol reduction: focus on ezetimibe and statins. Vasc Health Risk Manag . 4:267278.

Hang, Q., He, B., Yang, F ., Zeng, H., Zhao,Q. 2012. Effect of High-Cholesterol Diet on Serum Leptin and Blood Lipid in Rabbits. Journal of Animal and Veterinary Advances 11:1719-1721.

Hildemann, S.K., Barho, C., Karmann, B., Darius, H., Bestehorn, K. 2007. Dual cholesterol inhibition with ezetimibe /simvastatin treated hypercholesterolaemic patients with coronary heart disease or diabetes mellitus: prospective observation alcohort studies in 
clinical practice. Curr Med Res Opin 23:713-19.

Hiramitsu, S., Ishiguro, Y., Matsuyama, H., Yamada, K., Kato, K., Noba, M., Uemura, A., Yoshida, S., Matsubara, Y., Kani, A., Hasegawa, K., Hishida, H., Ozaki, Y. 2010. The effects of Ezetimibe on surrogate markers of cholesterol absorption and synthesis in Japanese patients with dyslipidemia. J Atheroscler Thromb 17: 106-114.

Hiriart, M., Sanchez-Soto, C., Diaz-Garcia, C.M., Castanares, D.T., Avitia, M., Velasco, M., Mas-Oliva, J., Macias-Silva, M., González-Villalpando, C., DelgadoCoello, B., Sosa-Garrocho, M., Vidaltamayo, R., Fuentes-Silva, D. 2014 Hyperinsulinemia is associated with increased soluble insulin receptor release from hepatocytes: Front Endocrinol (Lausanne). 19(5): 95.

Hydrie, Z.I., Qasim, R., Ahmadani, M.Y., Miyan, Z., Fawwad, A. Basit, A. 2007. Effect of simvastatin on insulin sensitivity in type 2 diabetic subjectic. Pak J Med Sci 23 (5): 755-759.

Inoguchi, T., Li, P., Umeda, F., Yu, H.Y., Kakimoto, M., Imamura, M., Aoki, T., Etoh, T., Hashimoto, T., Naruse, M., Sano, H., Utsumi, H., Nawata, H. 2000. High glucose level and free fatty acids stimulate reactive oxygen species production through protein kinase $\mathrm{C}$-dependent activation of NAD (P) $\mathrm{H}$ oxidase in cultured vascular cells. Diabetes. 49(11): 1939-45.

Iranloye, B.O., Arikawe, A.P., Rotimi,G. ,Sogbade .AO. 2011. Anti-diabetic and anti-oxidant effects of Zingiber Officinale on alloxan-induced and insulin-resistant diabetic male rats. Niger J Physiol Sci. 26(1): 89-96.

Ishak, N.A., Ismail, M., Hamid, M., Ahmad, Z., Abd Ghafa, S.A. 2013. Antidiabetic and Hypolipidemic Activities of Curculigo latifolia Fruit: Root Extract in High Fat Fed Diet and Low Dose STZ Induced Diabetic Rats: Evidence-Based Complementary and Alternative Medicine, Article ID 601838, 12.

Jafri, S. A., Sohail, A., Muhammad, Q. 2010. Hypoglycemic effect of ginger (Zingiber officinale) in alloxan induced diabetic rats (Rattusnorvagicus), Pak. Vet. J. 31: 160162.
Jang, W., Kim, Y., Seol, I. 2012. Antioxidant and Lipid-lowering Effects of Artemisia capillaris on a Rat Model of Hyperlipidemia. The Journal of Korean Oriental Medicine 33(2): 11-24.

Jialal, I., Stein, D., Balis, D., Grundy, S.M., Adams, B., Devaraj, S. 2001. Effect of hydroxymethyl glutaryl coenzyme A reductase inhibitor therapy on high sensitive C-reactive protein levels. Circulation 103: 1933-1935.

Kater, A.L., Batista, M.C., Ferreira, S.R. 2010. Synergistic effect of simvastatin and ezetimibe on lipid and pro-inflammatory profiles in pre-diabetic subjects. Diabetol Metab Syndr 7: 34-37.

Kenis, I., Tartakover-Matalon, S., Cherepnin, N., Drucker, L., Fishman, A., Pomeranz, M., Lishner, M. 2005. Simvastatin has deleterious effects on human first trimester placental explants. Hum. Reprod. 20(10): 2866-2872.

Kesavulu, M.M., Kameswararao, B., Apparao, Ch., Kumar, E.G.T.V., Harinarayan, C.V. 2002. Effect of $\omega-3$ fatty acids on lipid peroxidation and antioxidant enzyme status in type 2 diabetic patients. Diabetes Metab. 28: 20-26.

Khandouzi , N., Shidfar, F., Rajab, A., Rahideh, T., Hosseini, P. ,Taheri M. M. 2015. The effects of ginger on fasting blood sugar, hemoglobin a1c, apolipoprotein B, apolipoprotein a-I and malondialdehyde in type 2 diabetic patients.Iran J Pharm Res. 14(1): 131-40.

Koracevic, D., Koracevic, G., Djordjevic, V., Andrejevic, S., Cosic, V. 2001. Methods for the measurement of antioxidant activity in human fluids. J. Clin. Path., 54: 356 361.

Kostapanos, M.S., Spyrou, A.T., Tellis , C.C., Gazi, I.F., Tselepis, A.D., Elisaf, M. ,Liberopoulos, E.N. 2011. Ezetimibe treatment lowers indicators of oxidative stress in hypercholesterolemia subjects with high oxidative stress. Lipids. 46(4): 341-8.

Kuzelová, M., Adameová, A., Sumbalová, Z., Paulíková, I., Harcárová, A., Svec, P. ,Kucharská, J. 2008. The effect of simvastatin on coenzyme Q and antioxidant/oxidant balance in diabetichypercholesterolaemic rats. Gen Physiol Biophys. 27(4): 291-8. 
Le Roith, D., Zick, Y. 2001. Recent advances in our understanding of insulin action and insulin resistance. Diabetes Care 24: 58897.

Lenzen, S. 2008. The mechanisms of alloxanand streptozotocin- induced diabetes. Diabetologia 51: 216-226.

Li, Y., Tran, V.H., Duke, C.C., Roufogalis, B.D. 2012. Preventive and Protective Properties of Zingiber officinale (Ginger) in Diabetes Mellitus, Diabetic Complications and Associated Lipid and Other Metabolic Disorders: A Brief Review, Evidence Based Complementary and Alternative Medicine. 516870. doi: 10.1155/516870.

Ma, Z., Gingerich, R.L., Santiago, J.V., Klein, S., Smith, C.H., Landt, M. 1996. Radioimmunoassay of leptin in human plasma. Clinical Chemistry 42: 942-946.

Maeda, T., Horiuchi, N. 2009. Simvastatin suppresses leptin expression in 3T3-L1 adipocytes via activation of the cyclic AMP-PKA pathway induced by inhibition of protein prenylation. $\mathrm{J}$ Biochem 145:771-81.

Maehata, E., Yaho, M., Shiba, T., Yamakado, M., Inoue, M., Suzuki S. 2002.Insulin resistance index (HOMA-R) method. Nippon Rinsho 60:341-50.

Mahmoud, A.M., Moemen, L.A., Mostafa, A.M., Ghaleb, M.F., Farrag, M. Y., Aziz, M.A., Abdelhamid, M.A., Ahmed, N.S. 2014. Role of Advanced glycation End Products (AGEs) and Obesity in Diabetic Cataract Rats. Global Veterinaria 12(5): 700-709.

Mathe, D. 1995. Dyslipidemia and diabetes animal models. Diabetes Metab. 21(2): 106-11.

Mohamadin, A.M., Elberry, A.A., Abdel Gawad, H.S., Morsy, G.M. Al-Abbasi, F.A. 2011. Protective effects of simvastatin, a lipid-lowering agent, against oxidative damage in experimental diabetic rats. J. Lipids. 1-13.

Moutzouri, E., Liberopoulos, E., Mikhailidis, D.P., Kostapano, M.S., Kei, A.A., Milionis, H., Elisaf, M. 2011. Comparison of the effects of simvastatin vs. rosuvastatin vs. simvastatin / ezetimibe on parameters of insulin resistance: Int J Clin Pract.65(11): 1141-1148.

Obata, T., Yokota, I., Yokoyama, K., Okamoto, E., Kanezaki, Y., Tanaka, Y., Maegawa,
H., Teshigawara, K., Hirota, F., Yuasa, T., Kishi, K., Hattori, A., Hashida, S., Masuda ,K., Matsumoto, M., Matsumoto, T., Kashiwagi, A., Ebina, Y. The Soluble Insulin Receptor Study Group. 2007. Soluble Insulin Receptor Ectodomain Is Elevated in the Plasma of Patients With Diabetes. Diabetes. 56: 2028-2035.

Ohkawa, H., Ohishi, N., Yagi, K. 1979. Assay for lipid peroxidation in animal tissues by thiobarbituric acid reaction. Analytical Biochemistry 95: $351-358$.

Okada, K., Maeda, N., Kikuchi, K., Tatsukawa, M., Sawayama, Y., Hayashi, J. 2005. Pravastatin improves insulin resistance in dyslipidemic patients. $\mathrm{J}$ Atheroscler Thromb. 12(6):322-9.

Okada, K., Yagyu, H., Kotani, K., Miyamoto, M., Osuga, J., Nagasaka, S., Ishibashi, S. 2010. Lipid-lowering effects of ezetimibe for hypercholesterolemic patients with and without type 2 diabetes mellitus. Endocr J. 57(10): 903-8.

Papa, V., Russo, P., Gliozzo, B., Goldfine, I..D., Vigneri, R., Pezzino V. 1993.An intact and functional soluble form of the insulin receptor is secreted by cultured cells. Endocrinology 133: 1369-76.

Pari, L., Murugan, P., Rao, C.A. 2007. Influence of Cassia auriculata flowers on insulin receptors in streptozotocin induced diabetic rats: studies on insulin binding to erythrocytes; African Journal of Biochemistry Research. (7): 148-155.

Paul, P., Islam, M.K., Mustari, A., Khan, M.Z.I. 2012. Hypolipidemic effect of ginger extract in vanaspati fed rats, Bangl $\mathrm{J}$ Vet Med, 10(1-2): 93-6.

Poitout, V., Robertson, R.P. 2002. Minireview: secondary $\beta$-cell failure in type 2 diabetes - a convergence of glucotoxicity and lipotoxicity. Endocrinology 143(2): 339-342.

Račková, L., Cupáková, M., Tažký, A., Mičová, J., Kolek, E., Košt'álová D. 2013.Redox properties of ginger extracts: Perspectives of use of Zingiber officinale Rosc. as antidiabetic agent. Interdiscip Toxicol. 6(1): 26-33.

Ramanthan, M., Kaiswal, A.K., Bhattathacharya, Y.S. K. 1999. Superoxide dismutase catalase \& glutathrone peroxidase activity in the brain of STZ induced diabetes in rats Indian J. Axp. Biol., 37:182-183. 
Randle, P.J., Garland, P.B., Hales, C.N., Newsholme, E.A. 1963. The glucose fattyacid cycle. Its role in insulin sensitivity and the metabolic disturbances of diabetes mellitus. Lancet. 1: 785-789.

Rani, M.P., Padmakumari, P.K., Sankarikutti, B., Cherian, O.L., Nisha, V.M., Raghu, K.G. 2011. Inhibitory potential of ginger extracts against enzymes linked to type 2 diabetes, inflammation and induced oxidative stress. Int. J. Food. Sci. Nutr. 62: 106-110.

Samaha, S.R., Mohammed, S.M., Gabr, N.M., Al-Gendy, A.M., Mohamad, I.H. 2013. Evaluation of Simvastatin and/or Ezetimibe Treatment on Some Diabetic Complications in Streptozotocin Induced Diabetes in rats. J Am Sci. 9(4): 53-61.

Sánchez-Casas, P., Yusta, B., Blázquez E. 1995. Insulin-induced proteolysis of the insulin receptor alpha-subunit from rat liver does not occur in vivo but is prevented in vitro by blood serum proteinase inhibitors. Eur $\mathrm{J}$ Biochem 232:747-54.

Saravanan, R., Viswana, P., Pugalendi, K.V. 2006. Protective effect of urosolic acid on ethanol-Mediated experimental liver damage in rats. Life Sciences. 78: 713-718.

Saravanan, G., Ponmurugan, P., Deepa, M.A., Senthilkumar, B. 2014.Anti-obesity action of gingerol: effect on lipid profile, insulin, leptin, amylase and lipase in male obese rats induced by a high-fat diet. J Sci Food Agric. 10.1002/ 6642.

Shew, W.H., Jeng, C.Y., Lee, W.J., Lin, S.Y., Pei, D. ,Chen, Y.T. 2001. Simvastatin treatment in postprandial hypertriglyceridemia in type 2 diabetes mellitus patients with combined hyperlipidemia . Metab. 50: 355-9.

Sobal, G., Sinzinger, H. 2005. Effect of simvastatin on the oxidation of native and modified lipoproteins. Biochem Pharmacol. 70(8): 1185-1191.

Song, H., Shojima, N., Sakoda, H., Ogihara, T., Fujishiro, M., Katagiri, H., Anai, M., Onishi, Y., Ono, H., Inukai, K., Fukushima ,Y., Kikuchi, M., Shimano, H., Yamada, N., Oka, Y. ,Asano, T. 2002.Resistin is regulated by C/EBPs, PPARs, and signaltransducing molecules.Biochem Biophys Res Commun. 29(2): 291-8.

Srinivasan, K., Viswanad, B., Asrat, L., Kaul, C.L., Ramarao, P. 2005. Combination of high-fat diet-fed and low-dose streptozotocin-treated rat: a model for type 2 diabetes and pharmacological screening. Pharmacological Research. 52: 313-320.

Steel, R., Torrie, J., Dickey, D. 1997. Principles and procedures of Statistics: A Biometrical Approach, third ed., McGraw-Hill, New York, NY.

Stein, E.A. 1987. lipids, lipoproteins, and apolipoproteins. In NW Tietz, ed. Fundamentals of clinical chemistry, 3rd ed. Philadelphia: WB Saunders; 448.

Stewart, M.W., Laker, M.F., Dyer, R.G., Game, F., Mitcheson, J., Winocour, P.H., Alberti, K.G.M.M. $1993 . \quad$ Lipoprotein Compositional Abnormalities and Insulin Resistance in Type II Diabetic Patients with Mild Hyperlipidemia. Arteriosclerosis and Thrombosis 13(7): 1046-1052.

Subramanian, A., Pushpagandan, P., Ragesekharan, S., Evans, D. A., Latha, P.G., Valsaraj. R. 1996.Effect of artemisia pallens wall on blood glucose levels in normal and alloxan - induced diabetic rats. Journal of Ethnopharmacology, 50:13- 17.

Szendroedi, J., Anderwald, C., Krssak, M., Bayerle-Eder, M., Esterbauer, H., Pfeiler, G., Brehm, A., Nowotny, P., Hofer, A., Waldhäusl, W., Roden, M. 2009. Effects of high-dose simvastatin therapy on glucose metabolism and ectopic lipid deposition in nonobese type 2 diabetic patients. Diabetes Care. 32(2): 209-214.

Taskinen, M.R. 2003. Diabetic dyslipidaemia: from basic research to clinical practice. Diabetologia 46: 733-749.

Thakur, R. 2013. Study of Antioxidant, Antibacterial and Anti-Inflammatory Activity of Cinnamon ( Cinamomum Tamala ), Ginger ( Zingiber Officinale ) and Turmeric (Curcuma Longa). American Journal of Life Sciences. 273-277.

Tietz, N.W. ed. 1995. Clinical guide to laboratory tests. Third ed. Philadeiphia. WB Saunders, pp. 268-273.

Tsunoda, T., Nozue, T., Yamada, M., Mizuguchi, I., Sasaki, M., Michishita, I. 2013.Effects of ezetimibe on atherogenic lipoproteins and glucose metabolism in patients with diabetes and glucose intolerance. Diabetes Res Clin Pract 100: 46-52.

Turfaner, N., Uzun, H., Balci, H., Ercan, M.A., Karter, Y.H., Caner, M., Sipahioglu, F. , 
Genc, H. 2010. Ezetimibe therapy and its influence on oxidative stress and fibrinolytic activity. South Med J 103: 428-433.

Vishal, T., Bano, G., Khajuria, V., Parihar, A., Gupta S. 2005. Pleiotropic effects of statins. Indian J of Pharmacology 37: 7785.

Wilson, M.A., Miles, L.S.M., 1977. Radioimmunoassay of insulin. In hand book of Radioimmunoassay, G.E. Abraham (ed.), M. Dekker Inc., New York, pp. 257.

Yagi, K. 1998. Simple assay for the level of total lipid peroxides in serum or plasma. Methods Mol Biol 108: 101-6.

Yamaoka-Tojo, M., Tojo, T., Kosugi, R., Hatakeyama, Y., Yoshida,Y., Machida, Y., Aoyama ,N., Masuda, T., Izumi, T., 2009. Effects of ezetimibe add-on therapy for high-risk patients with dyslipidemia: Lipids in Health and Disease .8:41.

Yang, R., Shi, Y., Hao, G., Li, W., Le, G. 2008. Increasing oxidative stress with progressive hyperlipidemia in human: relation between malondialdehyde and atherogenic index. $\mathrm{J}$ Clin Biochem Nutr. 43: 154-158.

Yuasa, T., Amo, K., Ishikura, S., Nagaya ,H., Uchiyama, K., Hashida, S. Ebina, Y. 2014.
Development of in vitro model of insulin receptor cleavage induced by high glucose in HepG2 cells. Biochem Biophys Res Commun. 28(1): 236-43.

Zabut, B., Naji, H., Holi, B., Yousef, A. 2007. Leptin and Soluble Leptin Receptor among Obese Adults in the Gaza Strip. The Islamic University Journal (Series of Natural Studies and Engineering) 15: 127140.

Zhang, X., Dong, F., Ren, J., Driscoll, M.J. , Culver,B. 2005. High dietary fat induces NADPH oxidase-associated oxidative stress and inflammation in rat cerebral cortex. Experimental Neurology 191: 318325.

Zhong, Y., Wang, J., Gu, P., Shao, J., Luand, B., Jiang, S. 2012. Effect of Ezetimibe on Insulin Secretion in $\mathrm{db} / \mathrm{db}$ Diabetic Mice: Experimental Diabetes Research. ID 420854, 6 .

Zhou, J., Zhou, S., Tang, J, Zhang, K., Guang, L., Huang, Y., Xu, Y., Ying, Y., Zhang, L., Li, D. 2009. Protective effect of berberine on beta cells in streptozotocin- and highcarbohydrate/high-fat diet-induced diabetic rats. European Journal of Pharmacology 606: 262-268. 